\title{
Knowledge Level of Poultry Farmers Regarding Recommended Poultry Farming Practices
}

\author{
Hanuman Sahay Bunkar*, G. S. Bangarwa and Surendra Kumar \\ Department of Extension Education, SKN College of Agriculture, Jobner, Jaipur, India \\ *Corresponding author
}

\section{A B S T R A C T}

\section{Keywords}

Knowledge lelevel, Mean per cent score

Article Info

Accepted:

12 December 2020

Available Online:

10 January 2021
The poultry production in our country has made a significant progress over the years due to research and development thrust of the government and organized private sector. Poultry farming is considered as an important tool for self-employment as it offers vast scope for generating income in socially and economically backward areas. No other livestock production programme in our country has made as much progress in a short period as the poultry sector has made. The revolutionary changes made in poultry industry in the last four decades is a matter of great pride. The poultry sector provides livelihood to nearly one lakh farmers and contributes to a great extent to the national income. In Rajasthan, poultry industry is a live segment and source of revenue to the government. In the last five decades, Jaipur region has made manifold progress in the development of the poultry sector. Jaipur district is one such districts which has made a great headway in the promotion of poultry sector. With more than 14889 organized poultry farms, it has engaged more than 45000 people directly or indirectly.

\section{Introduction}

In India, about 65 per cent of the population is engaged in agriculture and rearing of livestock, subsidiary to agriculture. There exists a symbiotic relationship in men-landlivestock ecosystem. Livestock comprising of mainly cattle, buffaloes and poultry have a complementary, supplementary and sustainable relationship with crop under mixed farming system prevalent in our country. The origins of the poultry industry can be traced back to India. The modern crossbreed hen owes its ancestry to the Red Jungle fowl of India. However, poultry farming as a commercial enterprise is a recent phenomenon in our country. Poultry occupies a pivotal position among livestock based vocations to bring about rapid economic growth particularly benefiting the weaker sections of the farmers. Further, it needs low capital investment and yet assures quick returns, within weeks in case of broilers and months in case of layers.

\section{Materials and Methods}

The present study was conducted in Jaipur district of Rajasthan. The proposed district consisted of respondents from large, medium 
and small category of poultry farmers were selected a list of livestock census 2007 all the 200 organized poultry farmers. Data on that structured tool were collected personally from the respondents through face to face technique of interview. To arrive at the specific inferences, various statistical measures viz., percentage, mean percent score, mean and z-test etc., were used.

Measurement of knowledge level of farmers about improved poultry farming practices

To measure the knowledge level of respondents, a knowledge test developed by Narender Paul (2003) was adopted with slight modification like inclusion of various practices viz. vaccinations and management, record keeping and marketing along with increasing statements related to the practices of poultry farming and conversing the questions form after discussion with subject matter specialist of different poultry departments, Directorate of extension education R.A.U., Bikaner, and MPUAT, Udaipur, poultry department in veterinary college, Bikaner, poultry training centre, Jaipur, Animal Husbandry department Jaipur, Agricultural University S.K. Nagar, Gujarat, NDRI, Karnal, HAU, Hissar, IARI, New Delhi, poultry training centre, Ajmer, extensionists of department of extension education, S.K.N. College of Agriculture, Jobner but basic theme of questions was kept the same. Thirty questions along with sub questions about improved poultry farming practices in Jaipur district were included to measure the knowledge level of the farmers and equal weightage was given to each question, assuming that all the items included were equally difficult to understand, apply and one mark was given to right answer and zero for wrong answer. The following formula was used to work out the knowledge index.

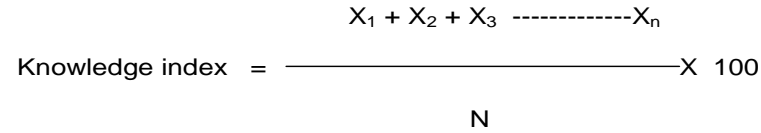

Where

$\mathrm{X}_{1}, \quad \mathrm{X}_{2}, \quad \mathrm{X}_{3}$ $X_{n}$ are correct answer for first second and uptoi ${ }^{\text {th }}$ question.

$\mathrm{N}=$ As the maximum possible score of the schedule.

The mean and standard deviation of the scores of all the respondents were computed for classifying the knowledge level in different categories based on the mean knowledge score and standard deviation. The farmers were categorized into three levels of knowledge i.e. low, medium and high based on mean and standard deviation. The categorization was done according to following considerations.

Low knowledge level $=$ Score below (Mean knowledge score - Standard Deviation)

Medium knowledge level $=$ Scores between (Mean knowledge score - Standard deviation to (Mean knowledge score + Standard Deviation))

High knowledge level $=$ Scores above (Mean knowledge score + Standard Deviation)

\section{Results and Discussion}

The findings regarding the knowledge level of poultry farmers about the recommended poultry farming practices have been presented in sub heads-

\section{Knowledge level of poultry farmers about the recommended poultry farming practices}

The findings regarding the knowledge level of poultry farmers about the recommended 
poultry farming practices have been presented in Table 1.

The data in table1. reveal the knowledge level of poultry farmers, where 125 respondents (59.68 per cent) were having medium knowledge whereas, 44 (19.59 per cent) and 31 (20.73 per cent) of respondents, were having high and low knowledge respectively about recommended poultry farming practices.

In case of knowledge level of large poultry farmers, 52 respondents (61.90 per cent) were having medium knowledge whereas, 30 (35.71 per cent) and 2 (2.39 per cent) of respondents, were having high and low knowledge respectively about recommended poultry farming practices.

The results shows that knowledge level of medium poultry farmers, 57 respondents (83.82 per cent) were having medium knowledge whereas, 10 (14.71 per cent) and 1 (1.47per cent) of respondents, were having high and low knowledge respectively about recommended poultry farming practices. The data shows knowledge level of small poultry farmers, 16 respondents (33.33 per cent) were having medium knowledge whereas, 4 (8.34 per cent) and 28 (58.33 per cent) of respondents were having high and low knowledge respectively about recommended poultry farming practices

These findings might have come due to the fact that the poultry farmers were associated with the poultry training centre for many years which might have raised their practical knowledge to medium and high level. However, those who were recently associated with the poultry training centre might have gained low level of knowledge.

The results are in concordance with the findings of Sankhala and Sharma (2001),
Choudhary and Panjabi (2002), Paul and Sharma (2004) and Jat and Yadav (2012) who reported that majority of the respondents possessed medium level of knowledge. However, the findings are in contradiction with those of Bhati and Sharma (2002) who revealed that majority of the respondents had low level of knowledge.

Category-wise comparison between knowledge levels of different categories of poultry farmers about recommended poultry farming practices

It is a general notion among the people that the knowledge about the recommended poultry farming practices varies in different categories of farmers. With this view in mind a comparison was made in the knowledge level about the recommended poultry farming practices of different categories of farmers by applying ' $Z$ ' test. The statistical data regarding this aspect have been presented in Table 2

The data in the table 2 show that the calculated value of ' $Z$ ' for large and medium farmers was 4.77 , which was statistically significant at one per cent level of probability.

Thus, it may be concluded that there was a significant difference between the knowledge level of large and medium farmers about recommended poultry farming practices. Hence, the null hypothesis $\mathrm{H}_{01.1}$ was rejected. Similarly a significant difference between large and small farmers has also been observed with regard to the knowledge level about recommended poultry farming practices, as the calculated value of ' $Z$ ' was 4.09, which was significant at one per cent level of probability. Hence the null hypothesis $\mathrm{H}_{01.2}$ was also rejected.

The data in table 2 further elucidate that the calculated value of ' $Z$ ' for medium and small 
farmers regarding knowledge level about recommended poultry farming practices (3.73) was significant at one per cent level of probability. Hence the null hypothesis $\mathrm{H}_{01.3}$ was rejected.

The ' $Z$ ' value indicate that there was a significant difference between the knowledge level of large and medium farmers, large and small farmers and medium and small farmers about recommended poultry farming practices. This shows that large farmers might have got more exposure, more contact with poultry training centers due to and more literacy as found in comparison to the medium and small poultry farmers.

Similar findings have also been reported by Jat and Yadav (2012).

\section{Practice-wise knowledge level of poultry farmers about the recommended poultry farming practices}

The practice wise knowledge level of poultry farmers about the recommended poultry farming practices was separately analyzed for all the eleven practices namely- chick procurement practices, brooding practices, litter management practices, temperature and light regulation practices, feeding practices, watering practices, equipment and spacing practices, disease and parasites practices, vaccination and management practices, sanitation practices and record keeping and marketing practices.

\section{Knowledge level of poultry farmers about recommended chick procurement practices of poultry farming}

The data in table 1 reveal that the highest knowledge of poultry farmers was found about "Optimum weight of one day old chick" (82.25 MPS), hence it was ranked first. The second and third ranks were assigned to the
"Chicks are released from the boxes at the earliest" (76.17 MPS) and "Uniformity of stock of the chicks" (71.62 MPS), respectively.

The practices "Withholding chicks in boxes for long time after delivery", "Reason for gentle and quick unloading of chicks", and "Improved breed of broiler" obtained the 67.13, 64.61, and 63.78 MPS and ranks were assigned fourth, fifth, and sixth, respectively.

The lowest rank was awarded to the practices "Concept of broiler" (61.71 MPS).

Regarding different categories of poultry farmers the large poultry farmers were having maximum knowledge about the practice "Chicks are released from boxes at the earliest" (92.86 MPS), whereas medium and small farmers were having maximum knowledge about "Optimum weight of one day old chick" with (98.53 MPS) and (70.83 MPS), respectively. The lowest knowledge scores of large and medium farmers were found having lowest knowledge about the "Improved breed of broiler" and "Withholding chicks in boxes for long time after delivery" with MPS 57.14 and 58.82, respectively whereas, small farmers were having lowest knowledge scores about "Reason for gentle and quick unloading of chicks" (50.00 MPS).

The data in table 1. also indicate that almost all the large poultry farmers were having higher knowledge (76.53 MPS) about all chick procurement practices except "Improved breed of broiler" and all small farmers were having lower knowledge (56.25 MPS) about all the seventh practices.

It might be concluded that the poultry farmers were having low knowledge about these seven chick procurement practices. This might be due to the fact that poultry farmers 
might be more awared about the required weight of the day old chicks which are to be kept for a healthy stock so gave more production.

The findings of this study support the findings of Jat and Yadav (2012).

\section{Knowledge level of poultry farmers about recommended brooding practices of poultry farming}

The data in table 2 reveal that the highest knowledge of poultry farmers was found about "Mixing of tonic in the water" (83.23 MPS), hence it was ranked first. The second and third ranks were assigned to the "Concept of chick guard" (79.31 MPS) and "Thickness of bedding material on which chicks are kept to brood" (78.82 MPS), respectively.

The practices "The beak of chicks are dipped after receiving from hatchery", "Types of brooding system", "Duration of heating brooder house before letting chicks to brood", "Ratio of dextrose and water to be offered to the brooding chicks", "Purpose of chick guard" and "Time of removal of chick guards" and "Method of providing feed to the brooding chicks" obtained the 73.98,72.49,72.48,71.03,69.32,63.88 and 63.32 MPS and ranks were assigned fourth, fifth, sixth, seventh, eighth, ninth and tenth, respectively. The lowest rank was awarded to the practice "Offering plenty of water to chicks before feeding" (59.08 MPS).

Regarding different categories of poultry farmers the large and medium poultry farmers were having maximum knowledge about the practice "Concept of chick guard" (92.86 MPS) and (86.76 MPS), respectively, whereas small poultry farmers were having maximum knowledge about "Mixing of tonic in the water to be given to chicks" (93.75 MPS). The lowest knowledge score of large poultry farmers was found about the "Purpose of chick guard" (61.90), whereas, medium and small poultry farmers were having lowest knowledge score about "Offering plenty of water to chicks before feeding" (60.29 MPS) and (47.92MPS), respectively.

The data in table 2 also indicate that almost all the medium poultry farmers were having higher knowledge (77.40 MPS) about all brooding practices. All small farmers were having lower knowledge (60.60 MPS) about all the eleven practices.

It might be concluded that poultry farmers were found to have higher knowledge about eleven brooding practices. These findings are in confirmation with the findings of Jat and Yadav (2012).

\section{Knowledge level of poultry farmers about recommended litter management practices of poultry farming}

The data in table 3 reveal that the highest knowledge of poultry farmers was found about "Percentage of moisture to be maintained in litter" (81.49 MPS), hence it was ranked first. The second and third ranks were assigned to the "Effect of dry litter on birds" (74.58 MPS) and "Basic qualities of the litter material” (74.37 MPS), respectively.

The practices "Treatment of wet litter and hard crust formed thereon", "Replacement of litter from a viable poultry unit" and "Thickness of litter material to be added every month" and "Improve the quality of dropping" were obtained the 73.20, 69.17, 68.89 and 67.36 MPS and ranks were assigned fourth, fifth, sixth and seventh, respectively.

The lowest rank was awarded to the practice "Thickness of litter material spread at the time of starting a lot" (62.84 MPS). 
Regarding different categories of poultry farmers the large and medium poultry farmers were having maximum knowledge about the practice "Percentage of moisture to be maintained in litter" (91.67 MPS) and (88.24 MPS), respectively whereas small poultry farmers were having maximum knowledge about "thickness of litter material to be added every month" (70.83 MPS).

The lowest knowledge scores of large and medium farmers were found about the "Thickness of litter material spread at the time of starting a lot" and "Thickness of litter material to be added every month" and obtained MPS 60.71 and 63.24, respectively whereas, small farmers were having lowest knowledge scores about "Basic qualities of the litter material" (56.15 MPS).

The data in table 3 also indicate that almost all the large poultry farmers were having higher knowledge (77.08 MPS) about all litter management practices. All small farmers were having lower knowledge (62.75 MPS) about all the eight practices..

It might be concluded that the poultry farmers were found to have higher knowledge about nine litter management practices, they were having higher knowledge about change litter regularly and thoroughly, clean and disinfect the poultry house in comparison.

These findings are in agreement with those of Kaved et al., (1997-98) and Jat and Yadav (2012).

Knowledge level of poultry farmers about recommended temperature and light regulation practices of poultry farming

The data in table 4 reveal that the highest knowledge of poultry farmers was found about "Temperature of poultry house during first to fifth weeks" (83.04 MPS), hence it was ranked first. The second and third ranks were assigned to the "Height of thermometer from the litter" (76.51 MPS) and "Degrees of temperature reduced every week inside the poultry house" (75.08 MPS), respectively.

The practices "Optimum light for grower" and "Temperature of poultry during fourth week till the sale of birds" were obtained the 74.85, and 64.02 MPS and ranks were assigned fourth and fifth, respectively.

The lowest rank was awarded to the practice "Source of lighting for birds" (58.09 MPS).

Regarding different categories of poultry farmers, the large and medium poultry farmers were having maximum knowledge about the practice "Temperature of poultry house during first to fifth weeks" and obtained MPS 96.43 and 98.53, respectively, whereas small farmers were having maximum knowledge about "Optimum light for grower" (62.50 MPS).

The lowest knowledge scores of large, medium and small farmers were found about the "Source of lighting for birds" and obtained MPS 61.90, 60.29 and 52.08, respectively.

The data in table 4 also indicate that almost all the medium poultry farmers were having higher knowledge (80.88 MPS) about temperature and light regulation practices. All small farmers were having lower knowledge (56.94 MPS) about all the sixth practices.

It might be concluded that the poultry farmers were found to have higher knowledge about six practices of temperature and light regulation. They give proper attention to the aspect of temperature and regulation while obtaining trainings. Because the poultry farmers might have more acquainted about demonstrations and trainings on use of non- 
electric energy sources and use such sources during power cuts or at critical periods through the various programme organized by poultry department for the poultry farmers.

These findings are in line with the findings of Satyanaran and Rao (2000) and Jat and Yadav (2012).

\section{Knowledge level of poultry farmers about recommended feeding practices of poultry farming}

The data in table 5 reveal that the highest knowledge of poultry farmers was found about "The consumed feed be recorded and tested daily" (80.40 MPS), hence it was ranked first. The second and third ranks were assigned to the "To prepare poultry feed by purchasing ingredient from the market" (80.02 MPS) and "Feed consumes a bird during in life" (80.01 MPS), respectively.

The practices "Use of crop for green feed", "Precautions taken in changing feed", "The percentage of protein, metaboligable energy and minerals in the poultry feed", "The level of antibiotic in poultry feed", Efficient feeding used for grower", "Proper ratio of poultry concentration and grinded maize", "Care should be taken during buying feed ingredients", "Feeders are required for layer", "The space should be filled in feeder", "Use of poultry manure in broiler feed", "The good quality of poultry feed", "Readymade feeds are preferred, "The various feeds in poultry", "The proportion of vitamins in the poultry feed", "The source of minerals in the poultry feed" and "Use of grit box in poultry house" were obtained the $79.48,77.83,77.65,76.47$, $76.35,75.95,74.79,74.39,73.10,73.03$, $72.41,71.73,70.95,70.61,69.06$ and 66.40 MPS and ranks were assigned IV,V, VI, VII, VIII, IX, X, XI, XII, XIII, XIV, XV, XVI, XVII, XVIII and XIX, respectively.
The lowest rank was awarded to the practices "Feed requirement of a day old chick" (65.71 MPS).

Regarding different categories of poultry farmers the large poultry farmers were having maximum knowledge about the practice "The percentage of protein, metaboligable energy and minerals in the poultry feed" (91.67 MPS), whereas medium and small farmers were having maximum knowledge about "Use of crop for green feed" and "The consumed feed be recorded and tested daily" and obtained MPS 94.12 and 68.75, respectively.

The lowest knowledge score of large poultry farmers was found about the "Use of grit box in poultry house" (69.05), whereas, medium and small poultry farmers were having lowest knowledge score about "Feed requirement of a day old chick" and "The proportion of vitamins in the poultry feed" and obtained MPS 64.71 and 56.25, respectively.

The data in table 5 also indicate that almost all the large poultry farmers were having higher knowledge (81.96 MPS) about all feeding practices. All small farmers were having lower knowledge (62.39 MPS) about all the twenty practices.

It might be concluded that the poultry farmers were found to have higher knowledge about twenty feeding practices have benefited through various activities organized by district poultry training centers which might have helped them to increase their knowledge about to purchase grinded maize and to prepare poultry concentrate, mix it in different ratios for different ages of birds and serve them accordingly.

These findings are in agreement with the findings of Khandekar and Sharma (2000) Jat and Yadav (2012). 
Knowledge level of poultry farmers about recommended watering practices of poultry farming

The data in table 6 reveal that the highest knowledge of poultry farmers was found about "Proper cleaning the water before serving to birds" (84.25 MPS), hence it was ranked first. The second and third ranks were assigned to the "The precautions taken in serving water to the chick" (83.45 MPS) and "Quantity of water is required per chick / day" (82.59 MPS), respectively.

The practices "Water distance maintained for birds", "Basic quality of water for poultry, "Cleaning the chick drinkers as recommended", " Quantity of water is required per grower / day", "Quantity of water is required per layer / day, "Method of watering for birds" and "Watering are filled in a day for birds" were obtained the 78.14, 77.73, 76.06, 75.75, 72.73, 72.71 and 68.75 MPS and ranks were assigned fourth, fifth, sixth, seventh, eighth, ninth and tenth, respectively.

The lowest rank was awarded to the practice "Source of water for birds" (67.97 MPS).

Regarding different categories of poultry farmers, the large poultry farmers were having maximum knowledge about the practice "Quantity of water is required per chick / day" (92.862 MPS), whereas medium and small farmers were having maximum knowledge about "The precautions taken in serving water to the chick" (94.12 MPS) and "Proper cleaning the water before serving to birds" (70.83 MPS), respectively.

The lowest knowledge scores of large poultry farmers were found about the "Watering are filled in a day for birds" and "Source of water for birds" (75.00 MPS), whereas, medium and small poultry farmers were having lowest knowledge scores about "Quantity of water is required per layer / day" and "Watering are filled in a day for birds" and obtained MPS 70.59 and 56.25, respectively. The data in table 6 also indicate that almost all the large poultry farmers were having higher knowledge (84.30 MPS) about all watering practices. All small farmers were having lower knowledge (62.87 MPS) about all the eleventh practices.

It might be concluded that the poultry farmers were found to have higher knowledge of eleventh watering practices. They were having more knowledge about regular supply of clean and fresh water. These findings are in line with the findings of Dena et al., (1995) Jat and Yadav (2012).

Knowledge level of poultry farmers about recommended equipment and spacing practices of poultry farming

The data in table 7 reveal that the highest knowledge of poultry farmers was found about "The feeding space should be provided to chick" (80.80 MPS), hence it was ranked first. The second and third ranks were assigned to the "Use of community nest" (78.34 MPS) and "Spacing required for nest box" (78.21 MPS), respectively.

The practices "Use of feeder", "Spacing required for per layer", "Spacing required for per grower", "Use of nest box", "Effect of inappropriate height of feeders on birds", "Use of feed scoop", "Floor space per chick required in brooder house", and "Required water space to the birds at different age" were obtained the 75.98, 73.61, 72.70, 72.39, 72.32, 72.28, 71.80 and 71.03 MPS and ranks were assigned fourth, fifth, sixth, seventh, eighth, ninth, tenth and eleventh, respectively.

The lowest rank was awarded to the practice "The dimensions of an ideal chick feeder" (66.85 MPS). 
Regarding different categories of poultry farmers, the large and medium poultry farmers were having maximum knowledge about the practice "Spacing required for nest box" and obtained MPS 89.29 and 91.18, respectively whereas, small poultry farmers were having maximum knowledge about "The feeding space should be provided to chick" (68.75 MPS).

The lowest knowledge scores of large and medium poultry farmers were found about the "The dimensions of an ideal chick feeder" and "Spacing required for per layer" and obtained MPS 64.29 and 73.53, respectively whereas, small poultry farmers were having lowest knowledge scores about "Required water space to the birds at different ages" (50.00 MPS).

The data in table 7 also indicate that almost all the large poultry farmers were having higher knowledge (82.64 MPS) about all equipment and spacing practices. All small farmers were having lower knowledge (58.68 MPS) about all the twelve practices.

It might be concluded that the poultry farmers were found to have higher knowledge about equipment and spacing practices and they were having higher knowledge about floor and feeder space required for different age group of birds.

These findings are in line with the findings of Sharma and Sani (2003), Paul et al., (2003) and Jat and Yadav (2012).

\section{Knowledge level of poultry farmers about the common diseases and parasites of poultry farming}

The data in table 8 and reveal that the highest knowledge of poultry farmers was found about "The common disease in poultry" (87.01 MPS), hence it was ranked first. The second and third ranks were assigned the "the common acto- parasites in poultry" (77.16 MPS) and "The common endo-parasites in poultry" (76.37 MPS), respectively.

The practices "The common symptoms of disease", "The birds treated against various diseases" and "The various diseases in poultry" were obtained the $75.86,69.94$, and 67.08 MPS and ranks were assigned fourth, fifth and sixth, respectively.

The lowest rank was awarded to the practice "The more prevalent disease in your area" (65.42 MPS).

Regarding different categories of poultry farmers, the large, medium and small poultry farmers were having maximum knowledge about the "The common disease in poultry" and obtained) MPS 91.67, 98.53 and 70.83, respectively.

The lowest knowledge scores of large and medium farmers were found about the "The various disease in poultry" and "The more prevalent disease in your area" and obtained MPS 70.24 and 61.76, respectively whereas, small farmers were having lowest knowledge scores about "The birds treated against various diseases" (56.25 MPS).

The data in table 8 also indicate that almost all the large poultry farmers were having higher knowledge (81.63 MPS) about all disease and parasites practices. All small farmers were having lower knowledge (62.79 MPS) about all the seven practices.

It might be concluded that the poultry farmers were found to have higher knowledge about disease and parasites practices. They might be more awared about to control internal as well as external disease of poultry. These findings are supported by the findings of Chauhan and Rathore (1997-98) and Jat and Yadav (2012). 
Table.1 Knowledge level of poultry farmers about the recommended poultry farming practices $n=200$

\begin{tabular}{|c|c|c|c|c|c|c|c|c|c|}
\hline \multirow{3}{*}{$\begin{array}{l}\text { S. } \\
\text { No. }\end{array}$} & \multirow{3}{*}{$\begin{array}{l}\text { Knowledge } \\
\text { level }\end{array}$} & \multicolumn{6}{|c|}{ Category of poultry farmers } & \multirow{2}{*}{\multicolumn{2}{|c|}{ Pooled }} \\
\hline & & \multicolumn{2}{|c|}{ Large } & \multicolumn{2}{|c|}{ Medium } & \multicolumn{2}{|c|}{ Small } & & \\
\hline & & $\mathbf{f}$ & $\%$ & f & $\%$ & $\mathbf{f}$ & $\%$ & f & $\%$ \\
\hline 1. & Low $(<72.78)$ & 2 & 2.39 & 1 & 1.47 & 28 & 58.33 & 31 & 20.73 \\
\hline 2. & $\begin{array}{l}\text { Medium ( from } \\
72.78 \text { to } 88.58 \text { ) }\end{array}$ & 52 & 61.90 & 57 & 83.82 & 16 & 33.33 & 125 & 59.68 \\
\hline \multirow[t]{2}{*}{3.} & High $(>88.58)$ & 30 & 35.71 & 10 & 14.71 & 4 & 8.34 & 44 & 19.59 \\
\hline & Total & 84 & 100.00 & 68 & 100.00 & 48 & 100.00 & 200 & 100.00 \\
\hline
\end{tabular}

Table.2 Category wise comparison between knowledge levels of poultry farmers about the recommended poultry farming practices $n=200$

\begin{tabular}{|l|l|l|l|l|l|l|}
\hline S. No. & Category one & Category two & \multicolumn{2}{|l|}{ Mean per cent score } & "Z" \\
\cline { 3 - 6 } & & Category one & Category two & value \\
\hline 1. & $\begin{array}{l}\text { Large farmers } \\
(\mathrm{N}=84)\end{array}$ & $\begin{array}{l}\text { Medium farmers } \\
(\mathrm{N}=68)\end{array}$ & 82.91 & 80.86 & $4.77 * *$ \\
\hline 2. & $\begin{array}{l}\text { Large farmers } \\
(\mathrm{N}=84)\end{array}$ & $\begin{array}{l}\text { Small farmers } \\
(\mathrm{N}=48)\end{array}$ & 82.91 & 62.70 & $4.09 * *$ \\
\hline 3. & $\begin{array}{l}\text { Medium farmers } \\
(\mathrm{N}=68)\end{array}$ & $\begin{array}{l}\text { Small farmers } \\
(\mathrm{N}=48)\end{array}$ & 80.86 & 62.70 & $3.73 * *$ \\
\hline
\end{tabular}

** Significant at 0.01 level of probability

Table.3 Knowledge level of poultry farmers about recommended chick procurement practices of poultry farming $n=200$

\begin{tabular}{|c|c|c|c|c|c|c|}
\hline \multirow{3}{*}{$\begin{array}{l}\text { S. } \\
\text { No }\end{array}$} & \multirow[t]{3}{*}{ Components of knowledge } & \multicolumn{5}{|c|}{ Category of poultry farmers } \\
\hline & & \multicolumn{5}{|c|}{ Mean per cent score } \\
\hline & & Large & Medium & Small & Pooled & Rank \\
\hline 1. & Optimum weight of one day old chick & 77.38 & 98.53 & 70.83 & 82.25 & I \\
\hline 2. & Concept of broiler & 59.52 & 73.53 & 52.08 & 61.71 & VII \\
\hline 3. & Improved breed of broiler & 57.14 & 77.94 & 56.25 & 63.78 & VI \\
\hline 4. & Uniformity of stock of the chicks & 90.48 & 76.47 & 47.92 & 71.62 & III \\
\hline 5. & $\begin{array}{l}\text { Reason for gentle and quick unloading } \\
\text { of chicks }\end{array}$ & 76.19 & 67.65 & 50.00 & 64.61 & $\mathrm{~V}$ \\
\hline 6. & $\begin{array}{l}\text { Withholding chicks in boxes for long } \\
\text { time after delivery }\end{array}$ & 82.14 & 58.82 & 60.42 & 67.13 & IV \\
\hline \multirow[t]{2}{*}{7.} & $\begin{array}{l}\text { Chicks are released from the boxes at } \\
\text { the earliest }\end{array}$ & 92.86 & 79.41 & 56.25 & 76.17 & II \\
\hline & Overall & 76.53 & 76.05 & 56.25 & 69.61 & \\
\hline
\end{tabular}


Table.4 Knowledge level of poultry farmers about the recommended brooding practices of poultry farming $n=200$

\begin{tabular}{|l|l|l|l|l|l|l|}
\hline \multirow{2}{*}{$\begin{array}{l}\text { S. } \\
\text { No }\end{array}$} & \multirow{2}{*}{ Components of knowledge } & \multicolumn{4}{|l|}{ Category of poultry farmers } \\
\cline { 3 - 6 } & & $\begin{array}{l}\text { Mean per cent score } \\
\text { Large }\end{array}$ & Medium & Small & Pooled & Rank \\
\hline 1. & $\begin{array}{l}\text { Duration of heating brooder house before letting } \\
\text { chicks to brood }\end{array}$ & 77.38 & 83.82 & 56.25 & 72.48 & VI \\
\hline 2. & Types of brooding system & 76.19 & 80.88 & 60.42 & 72.49 & V \\
\hline 3. & $\begin{array}{l}\text { Thickness of bedding material on which chicks } \\
\text { are kept to brood }\end{array}$ & 84.52 & 85.29 & 66.67 & 78.82 & III \\
\hline 4. & Method of providing feed to the brooding chicks & 66.67 & 69.12 & 54.17 & 63.32 & X \\
\hline 5. & Offering plenty of water to chicks before feeding & 69.05 & 60.29 & 47.92 & 59.08 & XI \\
\hline 6. & Concept of chick guard & 92.86 & 86.76 & 58.33 & 79.31 & II \\
\hline 7. & Purpose of chick guard & 61.90 & 79.41 & 66.67 & 69.32 & VIII \\
\hline 8. & Time of removal of chick guards & 71.43 & 76.47 & 43.75 & 63.88 & IX \\
\hline 9. & $\begin{array}{l}\text { Ratio of dextrose and water to be offered to the } \\
\text { brooding chicks }\end{array}$ & 83.33 & 73.53 & 56.25 & 71.03 & VII \\
\hline 10 & $\begin{array}{l}\text { The beak of chicks are dipped after receiving from } \\
\text { hatchery }\end{array}$ & 78.57 & 80.88 & 62.50 & 73.98 & IV \\
\hline 11 & Mixing of tonic in the water to be given to chicks & 80.95 & 75.00 & 93.75 & 83.23 & I \\
\hline & Overall & 76.62 & 77.40 & 60.60 & 71.54 & \\
\hline
\end{tabular}

Table.5 Knowledge level of poultry farmers about the recommended litter management practices of poultry farming $n=200$

\begin{tabular}{|c|c|c|c|c|c|c|}
\hline \multirow[t]{2}{*}{$\begin{array}{l}\text { S. } \\
\text { No }\end{array}$} & \multirow[t]{2}{*}{ Components of knowledge } & \multicolumn{5}{|c|}{$\begin{array}{l}\text { Category of poultry farmers } \\
\text { Mean per cent score }\end{array}$} \\
\hline & & Large & Medium & Small & Pooled & Rank \\
\hline 1. & Basic qualities of the litter material & 84.52 & 82.35 & 56.15 & 74.37 & III \\
\hline 2. & $\begin{array}{l}\text { Thickness of litter material spread at the } \\
\text { time of starting a lot }\end{array}$ & 60.71 & 63.24 & 64.58 & 62.84 & VIII \\
\hline 3. & $\begin{array}{l}\text { Thickness of litter material to be added } \\
\text { every month }\end{array}$ & 72.62 & 63.24 & 70.83 & 68.89 & VI \\
\hline 4. & $\begin{array}{l}\text { Percentage of moisture to be maintained in } \\
\text { litter }\end{array}$ & 91.67 & 88.24 & 64.58 & 81.49 & I \\
\hline 5. & Effect of dry litter on birds & 88.10 & 79.41 & 56.35 & 74.58 & II \\
\hline 6. & $\begin{array}{l}\text { Treatment of wet litter and hard crust } \\
\text { formed thereon }\end{array}$ & 75.00 & 77.94 & 66.67 & 73.20 & IV \\
\hline 7. & $\begin{array}{l}\text { Replacement of litter from a viable poultry } \\
\text { unit }\end{array}$ & 73.81 & 69.12 & 64.58 & 69.17 & $\mathrm{~V}$ \\
\hline \multirow[t]{2}{*}{8.} & Improve the quality of dropping & 70.24 & 73.53 & 58.33 & 67.36 & VII \\
\hline & Overall & 77.08 & 74.63 & 62.75 & 71.48 & \\
\hline
\end{tabular}


Table.6 Knowledge level of poultry farmers about the recommended temperature and light regulation practices of poultry farming $n=200$

\begin{tabular}{|c|c|c|c|c|c|c|}
\hline \multirow[t]{2}{*}{$\begin{array}{l}\text { S. } \\
\text { No }\end{array}$} & \multirow[t]{2}{*}{ Components of knowledge } & \multicolumn{5}{|c|}{$\begin{array}{l}\text { Category of poultry farmers } \\
\text { Mean per cent score }\end{array}$} \\
\hline & & Large & Medium & Small & Pooled & Rank \\
\hline 1. & $\begin{array}{l}\text { Temperature of poultry house during } \\
\text { first to fifth weeks }\end{array}$ & 96.43 & 98.53 & 54.17 & 83.04 & I \\
\hline 2. & Height of thermometer from the litter & 78.57 & 92.65 & 58.33 & 76.51 & II \\
\hline 3. & $\begin{array}{l}\text { Temperature of poultry during fourth } \\
\text { week till the sale of birds }\end{array}$ & 65.48 & 66.18 & 60.42 & 64.02 & V \\
\hline 4. & Source of lighting for birds & 61.90 & 60.29 & 52.08 & 58.09 & VI \\
\hline 5. & $\begin{array}{l}\text { Degrees of temperature reduced every } \\
\text { week inside the poultry house }\end{array}$ & 91.67 & 79.41 & 54.17 & 75.08 & III \\
\hline 6. & Optimum light for grower & 73.81 & 88.24 & 62.50 & 74.85 & IV \\
\hline & Overall & 77.98 & 80.88 & 56.94 & 71.93 & \\
\hline
\end{tabular}

Table.7 Knowledge level of poultry farmers about the recommended feeding practices of poultry farming $n=200$

\begin{tabular}{|c|c|c|c|c|c|c|}
\hline \multirow{3}{*}{$\begin{array}{l}\text { S. } \\
\text { No }\end{array}$} & \multirow[t]{3}{*}{ Components of knowledge } & \multicolumn{5}{|c|}{ Category of poultry farmers } \\
\hline & & \multicolumn{5}{|c|}{ Mean per cent score } \\
\hline & & Large & Medium & Small & Pooled & Rank \\
\hline 1. & The various feeds in poultry & 79.76 & 70.59 & 62.50 & 70.95 & XVI \\
\hline 2. & The good quality of poultry feed & 76.19 & 76.47 & 64.58 & 72.41 & XIV \\
\hline 3. & $\begin{array}{l}\text { The percentage of protein, metaboligable } \\
\text { energy and minerals in the poultry feed }\end{array}$ & 91.67 & 80.88 & 60.42 & 77.65 & VI \\
\hline 4. & The proportion of vitamins in the poultry feed & 76.19 & 79.41 & 56.25 & 70.61 & XVII \\
\hline 5. & The source of minerals in the poultry feed & 76.19 & 70.59 & 60.42 & 69.06 & XVIII \\
\hline 6. & The level of antibiotic in poultry feed & 83.33 & 79.41 & 66.67 & 76.47 & VII \\
\hline 7. & $\begin{array}{l}\text { Proper ratio of poultry concentration and } \\
\text { grinded maize }\end{array}$ & 85.71 & 83.82 & 58.33 & 75.95 & IX \\
\hline 8. & Feed requirement of a day old chick & 76.19 & 64.71 & 56.25 & 65.71 & $\mathrm{XX}$ \\
\hline 9. & Feed consumes a bird during in life & 89.29 & 88.24 & 62.50 & 80.01 & III \\
\hline 10. & Efficient feeding used for grower & 86.90 & 83.82 & 58.33 & 76.35 & VIII \\
\hline 11. & Feeders are required for layer & 82.14 & 76.47 & 64.58 & 74.39 & XI \\
\hline 12. & $\begin{array}{l}\text { Care should be taken during buying feed } \\
\text { ingredients }\end{array}$ & 79.76 & 77.94 & 66.67 & 74.79 & $\mathrm{X}$ \\
\hline 13. & Use of grit box in poultry house & 69.05 & 67.65 & 62.50 & 66.40 & XIX \\
\hline 14. & Use of crop for green feed & 79.76 & 94.12 & 64.58 & 79.48 & IV \\
\hline 15. & $\begin{array}{l}\text { To prepare poultry feed by purchasing } \\
\text { ingredient from the market }\end{array}$ & 88.10 & 85.29 & 66.67 & 80.02 & II \\
\hline 16. & Ready made feeds are preferred & 78.57 & 72.06 & 64.58 & 71.73 & $\mathrm{XV}$ \\
\hline 17. & The space should be filled in feeder & 80.95 & 77.94 & 60.42 & 73.10 & XII \\
\hline 18. & Precautions taken in changing feed & 85.71 & 85.29 & 62.50 & 77.83 & $\mathrm{~V}$ \\
\hline 19. & Use of poultry manure in broiler feed & 88.10 & 70.59 & 60.42 & 73.03 & XIII \\
\hline \multirow[t]{2}{*}{20.} & $\begin{array}{l}\text { The consumed feed be recorded and tested } \\
\text { daily }\end{array}$ & 85.71 & 86.76 & 68.75 & 80.40 & I \\
\hline & Overall & 81.96 & 78.60 & 62.39 & 74.31 & \\
\hline
\end{tabular}


Table.8 Knowledge level of poultry farmers about the recommended watering practice of poultry farming $n=200$

\begin{tabular}{|c|c|c|c|c|c|c|}
\hline \multirow{3}{*}{$\begin{array}{l}\text { S. } \\
\text { No }\end{array}$} & \multirow[t]{3}{*}{ Components of knowledge } & \multicolumn{5}{|c|}{ Category of poultry farmers } \\
\hline & & \multicolumn{5}{|c|}{ Mean per cent score } \\
\hline & & Large & Medium & Small & Pooled & Rank \\
\hline 1. & Basic quality of water for poultry & 91.67 & 85.29 & 56.26 & 77.73 & V \\
\hline 2. & Method of watering for birds & 78.57 & 75.00 & 64.58 & 72.71 & IX \\
\hline 3. & Water distance maintained for birds & 88.10 & 83.82 & 62.50 & 78.14 & IV \\
\hline 4. & $\begin{array}{l}\text { The precautions taken in serving water } \\
\text { to the chick }\end{array}$ & 91.67 & 94.12 & 64.58 & 83.45 & II \\
\hline 5. & $\begin{array}{l}\text { Cleaning the chick drinkers as } \\
\text { recommended }\end{array}$ & 86.90 & 80.88 & 60.42 & 76.06 & VI \\
\hline 6. & Watering are filled in a day for birds & 75.00 & 75.00 & 56.25 & 68.75 & $\mathrm{X}$ \\
\hline 7. & $\begin{array}{l}\text { Proper cleaning the water before } \\
\text { serving to birds }\end{array}$ & 89.29 & 92.65 & 70.83 & 84.25 & I \\
\hline 8. & $\begin{array}{l}\text { Quantity of water is required per chick / } \\
\text { day }\end{array}$ & 92.86 & 88.24 & 66.67 & 82.59 & III \\
\hline 9. & $\begin{array}{l}\text { Quantity of water is required per grower } \\
\text { / day }\end{array}$ & 77.38 & 85.29 & 64.58 & 75.75 & VII \\
\hline 10. & $\begin{array}{l}\text { Quantity of water is required per layer / } \\
\text { day }\end{array}$ & 80.95 & 70.59 & 66.67 & 72.73 & VIII \\
\hline \multirow[t]{2}{*}{11.} & Source of water for birds & 75.00 & 70.60 & 58.33 & 67.97 & XI \\
\hline & Overall & 84.30 & 81.95 & 62.87 & 76.37 & \\
\hline
\end{tabular}

Table.9 Knowledge level of poultry farmers about the recommended equipment and spacing practices of poultry farming $n=200$

\begin{tabular}{|l|l|l|l|l|l|l|}
\hline S. No & Components of knowledge & \multicolumn{4}{|l|}{ Category of poultry farmers } \\
\cline { 3 - 6 } & & \multicolumn{3}{l|}{ Mean per cent score } \\
\cline { 3 - 6 } & & Large & Medium & Small & Pooled & Rank \\
\hline 1. & The dimensions of an ideal chick feeder & 64.29 & 77.94 & 58.33 & 66.85 & XII \\
\hline 2. & The feeding space should be provided to chick & 86.90 & 86.76 & 68.75 & 80.80 & I \\
\hline 3. & Effect of inappropriate height of feeders on birds & 85.71 & 75.00 & 56.25 & 72.32 & VIII \\
\hline 4. & Floor space per chick required in brooder house & 79.76 & 79.41 & 56.25 & 71.80 & X \\
\hline 5. & Spacing required for per grower & 79.76 & 77.94 & 60.42 & 72.70 & VI \\
\hline 6. & Spacing required for per layer & 86.90 & 73.53 & 60.42 & 73.61 & V \\
\hline 7. & Use of community nest & 88.10 & 82.35 & 64.58 & 78.34 & II \\
\hline 8. & Use of feed scoop & 80.95 & 83.82 & 52.08 & 72.28 & IX \\
\hline 9. & Use of feeder & 83.33 & 77.94 & 66.67 & 75.98 & IV \\
\hline 10. & Use of nest box & 78.57 & 82.35 & 56.25 & 72.39 & VII \\
\hline 11. & Spacing required for nest box & 89.29 & 91.18 & 54.17 & 78.21 & III \\
\hline 12. & Required water space to the birds at different age & 88.10 & 75.00 & 50.00 & 71.03 & XI \\
\hline & Overall & 82.64 & 80.26 & 58.68 & 73.85 & \\
\hline
\end{tabular}


Table.10 Knowledge level of poultry farmers about the common diseases and parasites of poultry farming $n=200$

\begin{tabular}{|l|l|l|l|l|l|l|}
\hline S. No & Components of knowledge & \multicolumn{3}{|l|}{ Category of poultry farmers } \\
\cline { 3 - 7 } & & \multicolumn{3}{|l|}{ Mean per cent score } & \\
\cline { 3 - 7 } & & Large & Medium & Small & Pooled & Rank \\
\hline 1. & The various disease in poultry & 70.24 & 70.59 & 60.42 & 67.08 & VI \\
\hline 2. & The common disease in poultry & 91.67 & 98.53 & 70.83 & 87.01 & I \\
\hline 3. & The common symptoms of disease & 82.14 & 80.88 & 64.58 & 75.86 & IV \\
\hline 4. & The more prevalent disease in your area & 76.19 & 61.76 & 58.33 & 65.42 & VII \\
\hline 5. & The birds treated against various diseases & 78.57 & 75.00 & 56.25 & 69.94 & V \\
\hline 6. & The common endo-parasites in poultry & 84.52 & 77.94 & 66.67 & 76.37 & III \\
\hline 7. & The common acto- parasites in poultry & 88.10 & 80.88 & 62.50 & 77.16 & II \\
\hline & Overall & 81.63 & 77.94 & 62.79 & 74.12 & \\
\hline
\end{tabular}

Table.11 Knowledge level of poultry farmers about the recommended vaccination and management practices of poultry farming $n=200$

\begin{tabular}{|c|c|c|c|c|c|c|}
\hline \multirow{3}{*}{$\begin{array}{l}\text { S. } \\
\text { No }\end{array}$} & \multirow[t]{3}{*}{ Components of knowledge } & \multicolumn{5}{|c|}{ Category of poultry farmers } \\
\hline & & \multicolumn{5}{|c|}{ Mean per cent score } \\
\hline & & Large & Medium & Small & Pooled & Rank \\
\hline 1. & The main vaccine used in poultry & 85.71 & 97.06 & 60.42 & 81.06 & I \\
\hline 2. & $\begin{array}{l}\text { The timing of vaccination of poultry } \\
\text { birds }\end{array}$ & 91.67 & 83.82 & 58.33 & 77.94 & II \\
\hline 3. & $\begin{array}{l}\text { The chemicals used to control acto- } \\
\text { parasites }\end{array}$ & 80.92 & 67.65 & 66.67 & 71.75 & VI \\
\hline 4. & $\begin{array}{l}\text { The chemicals used to control endo- } \\
\text { parasites }\end{array}$ & 84.52 & 69.12 & 64.58 & 72.74 & V \\
\hline 5. & $\begin{array}{l}\text { Control measures taken to minimize the } \\
\text { incidence of disease }\end{array}$ & 82.14 & 86.76 & 56.25 & 75.05 & IV \\
\hline 6. & $\begin{array}{l}\text { Precautions are required to prevent } \\
\text { disease in birds }\end{array}$ & 83.33 & 86.76 & 62.50 & 77.53 & III \\
\hline 7. & $\begin{array}{l}\text { The vaccination schedule to be followed } \\
\text { for poultry disease }\end{array}$ & 80.98 & 77.94 & 47.92 & 68.93 & VII \\
\hline & Overall & 84.18 & 81.30 & 59.52 & 75.00 & \\
\hline
\end{tabular}


Table.12 Knowledge level of poultry farmers about the recommended sanitation practices of poultry farming $n=200$

\begin{tabular}{|c|c|c|c|c|c|c|}
\hline \multirow{3}{*}{$\begin{array}{l}\text { S. } \\
\text { No }\end{array}$} & \multirow[t]{3}{*}{ Components of knowledge } & \multicolumn{5}{|c|}{ Category of poultry farmers } \\
\hline & & \multicolumn{5}{|c|}{ Mean per cent score } \\
\hline & & Large & Medium & Small & Pooled & Rank \\
\hline 1. & $\begin{array}{l}\text { The good sanitary conditions to be } \\
\text { maintained at poultry farm }\end{array}$ & 91.67 & 76.47 & 64.58 & 77.57 & II \\
\hline 2. & $\begin{array}{l}\text { The outside persons are not allowed in } \\
\text { poultry farm }\end{array}$ & 63.10 & 66.18 & 56.25 & 61.84 & VII \\
\hline 3. & $\begin{array}{l}\text { The phenyl soaked foot pad placed at the } \\
\text { door of the shed }\end{array}$ & 92.86 & 92.65 & 54.17 & 79.89 & I \\
\hline 4. & $\begin{array}{l}\text { Proper cleaning of shed done in new lot is } \\
\text { to be started }\end{array}$ & 79.76 & 89.71 & 58.33 & 75.93 & III \\
\hline 5. & The record of disposing the dead birds & 77.38 & 80.88 & 60.42 & 72.89 & IV \\
\hline 6. & Painting floor with lime & 75.00 & 61.76 & 66.67 & 67.81 & VI \\
\hline \multirow[t]{2}{*}{7.} & The bio-security measures in poultry & 84.52 & 76.47 & 50.00 & 70.33 & V \\
\hline & Overall & 80.61 & 77.73 & 58.63 & 72.32 & \\
\hline
\end{tabular}

Table.13 Knowledge level of poultry farmers about the recommended record keeping and marketing practices of poultry farming $n=200$

\begin{tabular}{|l|l|l|l|l|l|l|}
\hline \multirow{2}{*}{$\begin{array}{l}\text { S. } \\
\text { No }\end{array}$} & \multirow{2}{*}{ Components of knowledge } & \multicolumn{4}{|l|}{ Category of poultry farmers } \\
\cline { 3 - 7 } & & Mean per cent score & \\
\cline { 3 - 8 } & & Large & Medium & Small & Pooled & Rank \\
\hline 1. & Record keeping of poultry feeds & 85.71 & 85.29 & 72.92 & 81.30 & I \\
\hline 2. & Record of birds mortality & 76.19 & 76.47 & 64.58 & 72.41 & IV \\
\hline 3. & Record of day to day expenditure & 76.19 & 69.12 & 58.33 & 67.88 & VI \\
\hline 4. & Price record of poultry products & 82.14 & 80.88 & 60.42 & 74.48 & III \\
\hline 5. & $\begin{array}{l}\text { Appropriate time to sell the poultry } \\
\text { products }\end{array}$ & 80.95 & 69.12 & 58.34 & 69.46 & V \\
\hline 6. & Record of poultry health & 80.95 & 79.41 & 66.67 & 75.67 & II \\
\hline 7. & Demand record of poultry products & 63.10 & 64.71 & 75.00 & 67.60 & VII \\
\hline & Overall & 77.89 & 75.00 & 65.17 & 72.68 & \\
\hline
\end{tabular}


Table.14 Practice-wise overall knowledge level of the poultry farmers about recommended poultry farming practices $n=200$

\begin{tabular}{|c|c|c|c|c|c|c|}
\hline \multirow[t]{3}{*}{ S. No } & \multirow[t]{3}{*}{ Major practices of knowledge } & \multicolumn{5}{|c|}{ Category of poultry farmers } \\
\hline & & \multicolumn{5}{|c|}{ Mean per cent score } \\
\hline & & Large & Medium & Small & Pooled & Rank \\
\hline 1 & Chick procurement practices & 76.53 & 76.05 & 56.25 & 69.61 & XI \\
\hline 2 & Brooding practices & 93.65 & 94.61 & 74.07 & 87.44 & I \\
\hline 3 & Litter management practices & 77.08 & 74.63 & 62.76 & 71.49 & IX \\
\hline 4 & $\begin{array}{l}\text { Temperature \& light regulation } \\
\text { practices }\end{array}$ & 77.98 & 80.88 & 56.94 & 71.91 & VIII \\
\hline 5 & Feeding practices & 81.96 & 78.60 & 62.39 & 71.32 & $\mathrm{X}$ \\
\hline 6 & Watering practices & 84.31 & 81.95 & 62.88 & 76.38 & II \\
\hline 7 & Equipment and spacing practices & 82.64 & 80.27 & 58.68 & 73.86 & V \\
\hline 8 & Disease and parasites & 81.63 & 77.94 & 62.80 & 74.12 & IV \\
\hline 9 & $\begin{array}{l}\text { Vaccination and management } \\
\text { practices }\end{array}$ & 84.18 & 81.30 & 59.52 & 75.00 & III \\
\hline 10 & Sanitation practices & 80.61 & 77.73 & 58.63 & 72.32 & VII \\
\hline \multirow[t]{2}{*}{11} & $\begin{array}{l}\text { Record keeping and marketing } \\
\text { practices }\end{array}$ & 77.89 & 75.00 & 65.18 & 72.69 & VI \\
\hline & Overall & 81.67 & 79.90 & 61.82 & 74.19 & \\
\hline
\end{tabular}

Knowledge level of poultry farmers about recommended vaccination and management practices of poultry farming

The data in table 9 a reveal that the highest knowledge of poultry farmers was found about "The main vaccine used in poultry" (81.06 MPS), hence it was ranked first. The second and third ranks were assigned to the "The timing of vaccination of poultry birds" (77.94 MPS) and "Precautions are required to prevent disease in birds" (77.53 MPS), respectively.

The practices "Control measures taken to minimize the incidence of disease", "The chemicals used to control endo- parasites" and "The chemicals used to control actoparasites" were obtained the 75.05, 72.74 and 71.75 MPS and ranks were assigned fourth, fifth and sixth, respectively.

The lowest rank was awarded to the practice "The vaccination schedule to be followed for poultry disease" (68.93 MPS).
Regarding different categories of poultry farmers, the large and medium poultry farmers were having maximum knowledge about the practice "The timing of vaccination of poultry irds" and "The main vaccine used in poultry" and obtained MPS 91.67 and 97.06, respectively whereas, small poultry farmers were having maximum knowledge about "The chemicals used to control actoparasites" (66.67 MPS). The data in table 9 also indicate that almost all the large poultry farmers were having higher knowledge (84.18 MPS) about recommended vaccination and management practices. All small farmers were having lower knowledge (59.52 MPS) about all the seventh practices. The lowest knowledge scores of large and medium farmers were found about the "The chemicals used to control acto-parasites" and obtained MPS 80.95 and 67.65, respectively whereas, small farmers were having lowest knowledge scores about "The vaccination schedule to be followed for poultry disease" (47.92 MPS). It might be concluded that the poultry farmers were found to have higher knowledge of 
seventh vaccination practices, they have more knowledge about a precise and regular vaccination schedule for each flock.

These findings are supported by the findings of Satyanarayana and Roa, (2000) and Jat and Yadav (2012).

Knowledge level of poultry farmers about recommended sanitation practices of poultry farming

The data in table 10 reveal that the highest knowledge of poultry farmers was found about "The phenyl soaked foot pad placed at the door of the shed" (79.89 MPS), hence it was ranked first. The second and third ranks were assigned to the "The good sanitary conditions to be maintained at poultry farm" (77.57 MPS) and "proper cleaning of shed done in new lot is to be started" (75.93 MPS), respectively.

The practices "The record of disposing the dead birds", "The bio-security measures in poultry" and "Painting floor with lime" were obtained the 72.89, 70.33 and 67.81 MPS and ranks were assigned fourth, fifth and sixth, respectively.

The lowest rank was awarded to the practices "The outside persons are not allowed in poultry farm" (61.84 MPS).

Regarding different categories of poultry farmers, the large and medium poultry farmers were having maximum knowledge about the practice "The phenyl soaked foot pad placed at the door of the shed" and obtained MPS 92.86 and 92.65, respectively whereas, small poultry farmers were having maximum knowledge about "Painting floor with lime" (66.67MPS).

The lowest knowledge scores of large, medium poultry farmers were having lowest knowledge scores about the "The outside persons are not allowed in poultry farm" and "Painting floor with lime" and obtained MPS 63.10 and 61.76 , respectively whereas, small poultry farmers were having low knowledge about "The bio-security measures in poultry" (50.00 MPS).

The data in table 10 also indicate that almost all the large poultry farmers were having higher knowledge (80.61 MPS) about all sanitation practices. All small farmers were having lower knowledge (58.63 MPS) about all the seven practices.

It might be concluded that the poultry farmers were found to have higher knowledge of seven satiation practices, they were more award about the reason of restrictions to the visits of outsiders in the poultry farm. These findings are in agreement with the findings of Choudhary and Panjabi (2002) and Jat and Yadav (2012).

\section{Knowledge level of poultry farmers about recommended record keeping and marketing practices of poultry farming}

The data in table 11 reveal that the highest knowledge of poultry farmers was found about " Record keeping of poultry feeds" (81.30 MPS), hence it was ranked first. The second and third ranks were assigned to the "Record of poultry health" (75.67 MPS) and "Price record of poultry products" (74.48 MPS), respectively.

The practices "Record of birds mortality", "Appropriate time to sell the poultry products" and "Record of day to day expenditure" were obtained the 72.41, 69.46 and 67.88 MPS and ranks were assigned fourth, fifth and sixth, respectively. The lowest rank was awarded to the practice "Demand record of poultry products" (67.60 MPS). 
Regarding different categories of poultry farmers, the large and medium poultry farmers were having maximum knowledge about the practice "record keeping of poultry feeds" and obtained MPS 85.71 and 85.29, respectively whereas, small poultry farmers were having maximum knowledge about "Demand record of poultry products" (75.00 MPS).

The lowest knowledge scores of large and medium poultry farmers were having lowest knowledge about the practice "Demand record of poultry products" and obtained MPS 63.10 and 64.71, respectively whereas, small poultry farmers were having lowest knowledge about "Record of day to day expenditure" (58.33 MPS).

The data in table 11 also indicate that almost all the large poultry farmers were having higher knowledge (77.89 MPS) about all record keeping and marketing practices. All small farmers were having lower knowledge (65.17 MPS) about all the seven practices.

It might be concluded that the poultry farmers were found to have higher knowledge of seven records keeping and marketing practices have benefited through poultry development programmes organized by district poultry officers. The poultry farmers were having good transportation facility for taking their product to the market. They were more awared about marketing network and benefits of direct marketing to minimize the role of middle men. These findings are supported by the findings of Sankhala and Sharma (2001) and Jat and Yadav (2012).

\section{Practice-wise overall knowledge level of the poultry farmers about recommended poultry farming practices}

Practice wise over all knowledge level of poultry farmers about recommended poultry farming practices was measured, to obtain the overall knowledge regarding various recommended major practices of poultry farming possessed poultry farmers. The overall scores for each major practice was summed up and results have been presented in table 12 .

The data in table 12 and reveal that the highest knowledge of poultry farmers was found about "Brooding practices" (87.44 MPS), hence it was ranked first. The second and third ranks were assigned to the "Watering practices" (76.38 MPS) and "Vaccination and management practices" (75.00 MPS), respectively.

The practices "Disease and parasites", "Equipment and spacing practices", "Record keeping and marketing practices", "Sanitation practices", "Temperature \& light regulation practices", "Litter management practices", and "Feeding practices" were obtained the 72.12, 73.86, 72.69, 72.32, 71.91, 71.49 and 71.32 MPS and ranks were assigned fourth, fifth, sixth, seventh, eighth, ninth and tenth, respectively. The lowest rank was awarded to the practice "Chick procurement practices" (69.61 MPS).

Regarding different categories of poultry farmers, the large, medium and small poultry farmers were having maximum knowledge about the practice "Brooding practices" and obtained MPS 93.65, 94.61 and 74.07, respectively.

The lowest knowledge scores of large and small poultry farmers were found about the "Chick procurement practices" and obtained MPS 76.53 and 56.25, respectively whereas, medium poultry farmers were having lowest knowledge scores about "Litter management practices" (74.63 MPS). The data in table 5.2.3.12 also indicate that almost all the large poultry farmers were having higher 
knowledge (81.67 MPS) about all equipment and spacing practices. All small farmers were having lower knowledge (61.82 MPS) about all the eleventh practices.

These findings are in line with the findings of Paul et al., (2003) and Jat and Yadav (2012).

In conclusion it was observed that 61.90 per cent of the large farmers were found to have medium knowledge level about the recommended poultry farming practices, While 35.71 per cent large farmers were found to have high knowledge level whereas, 2.39 per cent farmers were found to have low knowledge level regarding recommended poultry farming practices.

\section{References}

Bhati, D.S. and Sharma, S.K. (2002). "Knowledge level of different categories of farmers about improved mustard production technology". Raj. Journ. ofExtn. Edn., X: 23-27.

Choudhary, M.C. and Panjabi, N.K. (2002). "Knowledge assessment of rural poors about improved practices of social forestry". Raj. Journ. ofExtn. Edn.,X: 28-33.

Chauhan, N.B. and Rathore, O.S. (1997-98). "Sway of selected factors on technical knowledge of small peasants". Guj. Journ. ofExtn. Edn., Vol. VIII \& IX: 9597.

Dena, S.S.; Khandekar, Nita and Sinha, S.P. (1995). "Factors associated with tranees' knowledge about poultry health control measures". Ind. J. of Poultry Sci., XXX
(1): 92-93.

Jat, S.M. and Yadav, J.P. (2012). "Knowledge level of poultry farmers about recommended poultry farming practices". Indian Research Journal of Ext. Edu. Bhati, D.S. and Sharma, S.K. (2002). "Knowledge level of different categories of farmers about improved mustard production technology". Raj. Journ. ofExtn. Edn., X: 23-27.12 (1): 51-54.

Kavad, S.D., Patel, R.B. and Joshi, V.D. (199798). "Impact of cooperative sugar factories on sugarcane growers of south Gujarat". Guj. Journ. ofExtn. Edn.:Vol VIII \& IX: 125-127.

Khandekar, N. and Sharma, R.P. (2000). "Investigation on technology gap in small scale poultry farming". Indian Journ. of Poultry Science, XXXV (3): 262-265.

Paul, N. and Sharma, V.P. (2004). "Problem and prospects of poultry enterprise in Kathua district of Jammu and Kashmir". Ph.D. Thesis, RCA, Udaipur.

Sankhala, G. and Sharma, B.M. (2001). "Role performance of farm women in agriculture and dairy husbandry: An analysis." Raj. J. of Extn. Edu., VIII \& IX: 10-13.

Satyanarayana, G. and Rao, R.P. (2002). "Knowledge of oilpalm growers" Journ. ofExtn. Edn. Vol. XI (3): 2866-2870.

Sharma, K. and Saini, G.S. (2003). "Knowledge of the secretaries of milk co-operative societies regarding animal husbandry practices". Ind. Res. J. of Extn. Edu., 3 (1): 84-86.

\section{How to cite this article:}

Hanuman Sahay Bunkar, G. S. Bangarwa and Surendra Kumar. 2021. Knowledge Level of Poultry Farmers Regarding Recommended Poultry Farming Practices. Int.J.Curr.Microbiol.App.Sci. 10(01): 820-838. doi: https://doi.org/10.20546/ijcmas.2021.1001.101 